\title{
TEKNOLOGI PEMBELAJARAN BERBASIS ICT (PENERAPAN COMPUTER BASED TEST)
}

\author{
Oleh : Rosdiana \\ Fakultas Tarbiyah dan Ilmu Keguruan IAIN Palopo
}

\begin{abstract}
Abstrak:
Teknologi Berbasis Komputer merupakan cara-cara memproduksi dan menyampaikan bahan dengan menggunakan perangkat yang bersumber pada mikroprosesor. Baru-baru ini pemerintah menggunakan sistem Computer Based Test (CBT) bagi beberapa sekolah untuk diaplikasikan pada test Ujian Nasional 2015 Tingkat Menengah Atas. Computer Based Test atau dikenal dengan Ujian berbasis komputer ditujukan khusus kepada beberapa sekolah yang mempunyai fasilitas komputer yang dapat digunakan oleh siswa peserta Ujian Nasional (UN). UN berbasis komputer bukan berarti secara daring atau online, melainkan hanya dilakukan lewat perangkat komputer dan tak terhubung internet. Tes Berbasis Komputer (Computer Based Test, CBT) merupakan tes/evaluasi yang diselenggarakan dengan menggunakan komputer. Karakteristik dari tes ini sama dengan tes konvensional yaitu menggunakan satu perangakat tes untuk beberapa peserta dengan panjang tes yang sama (fixed test length). Perbedaannya terletak pada teknik penyampaian (delivery) butir soal yang tidak lagi meggunakan kertas (paperless), baik untuk naskah soal maupun lembar jawaban. Sistem skoring atau koreksi langsung dilakukan oleh komputer. Biasanya peserta bisa mengerjakan dan melihat butir soal dari nomor pertama sampai dengan terakhir.
\end{abstract}

Kata Kunci : Teknologi Pembelajaran, Komputer, ICT, CBT, Media Pembelajaran, Ujian.

\section{A. PENDAHULUAN}

Istilah teknologi pembelajaran bukanlah hal yang baru, apalagi dikalangan orang-orang yang berkecimpung dalam dunia pendidikan. Namun seiring waktu ternyata istilah teknologi pembelajaran mengalami evolusi pengertian. Ini terbukti dengan beragam pengertian yang dimunculkan oleh para pakar berkenaan dengan istilah tersebut. Awalnya teknologi pembelajaran dipandang sebagai teknologi peralatan, karena berkaitan dengan penggunaan peralatan, media dan sarana untuk mencapai tujuan pendidikan atau dengan kata lain mengajar dengan alat bantu audio-visual.

Teknologi Pembelajaran merupakan gabungan dari tiga aliran yang saling berkepentingan, yaitu media dalam pendidikan, psikologi pembelajaran dan pendekatan sistem dalam pendidikan ${ }^{l}$.

\footnotetext{
${ }^{1}$ Akhmad Sudrajat, Teknologi Pembelajaran (2008)
} 
Penerapan Teknologi pembelajaran hingga saat inipun terus mengalami peningkatan seiring dengan perkembangan teknologi yang ada. Teknologi Informasi dan Komunikasi, Information and Communication Technologi (ICT) adalah salah satu media yang menjadikan Teknologi Pembelajaran ini menjadi semakin modern. Maraknya beberapa aplikasi ICT dengan menggunakan media komputer sangat memungkinkan pengembangan teknologi pembelajaran pun semakain berkembang. Di beberapa daerah, pengembangan Teknologi Pembelajaran untuk beberapa instansi pendidikan terus mengalami pembenahan baik dari segi profesionalitas pengajarnya maupun bahan ajar yang digunakan, yang semuanya berbasis komputer. Ada banyak sistem pembelajaran yang menggunakan alat bantu komputer, salah satunya yaitu aplikasi pembelajaran yang mengacu pada teknologi berbasis Multimedia dan berbasis Web (Internet).

Saat ini bukan hanya proses pembelajarannya yang berbasis ICT, tetapi tes/evaluasi berbasis komputer (CBT) dengan berbagai model aplikasi pun mulai marak dikembangkan.

Seperti diketahui bersama, baru-baru ini pemerintah menggunakan sistem Computer Based Test (CBT) bagi beberapa sekolah untuk diaplikasikan pada test Ujian Nasional 2015 Tingkat Menengah Atas. Computer Based Test atau dikenal dengan Ujian berbasis komputer ditujukan khusus kepada beberapa sekolah yang mempunyai fasilitas komputer yang dapat digunakan oleh siswa peserta Ujian Nasional (UN). UN berbasis komputer bukan berarti secara daring atau online, melainkan hanya dilakukan lewat perangkat komputer dan tak terhubung internet.

\section{B. Teknologi Berbasis Komputer.}

Sebelum kita membahas lebih jauh tetang Computer based Test, maka penjelasan tentang Teknologi berbasis komputer yang diterapkan dalam Teknologi Pembelajaran akan kami paparkan terlebih dahulu.

Teknologi Berbasis Komputer merupakan cara-cara memproduksi dan menyampaikan bahan dengan menggunakan perangkat yang bersumber pada mikroprosesor. Pada dasarnya, teknologi berbasis komputer menampilkan informasi kepada pembelajar melalui tayangan di layar monitor. Berbagai aplikasi komputer biasanya disebut "computer-based intruction (CBI)", "computer assisted instruction (CAI"), atau "computer-managed instruction (CMI)". 
33 | al-Khwarizmi, Volume III, Edisi 2, Oktober 2015, Hal. 31 - 38

Aplikasi-aplikasi ini hampir seluruhnya dikembangkan berdasarkan teori perilaku dan pembelajaran terprogram, akan tetapi sekarang lebih banyak berlandaskan pada teori kognitif. Aplikasi-aplikasi tersebut dapat bersifat : (1) tutorial, pembelajaran utama diberikan, (2) latihan dan pengulangan untuk membantu pembelajar mengembangkan kefasihan dalam bahan yang telah dipelajari sebelumnya, (3) permainan dan simulasi untuk memberi kesempatan menggunakan pengetahuan yang baru dipelajari; dan (5) dan sumber data yang memungkinkan pembelajar untuk mengakses sendiri susunan data melalui tata cara pengakasesan (protocol) data yang ditentukan secara eksternal.

Teknologi komputer, baik yang berupa perangkat keras maupun perangkat lunak biasanya memiliki karakteristik sebagai berikut :

1) Dapat digunakan secara secara acak, disamping secara linier

2) Dapat digunakan sesuai dengan keinginan Pembelajar, disamping menurut cara seperti yang dirancang oleh pengembangnya.

3) Gagasan-gagasan biasanya diungkapkan secara abstrak dengan menggunakan kata, simbol maupun grafis.

4) Prinsip-prinsip ilmu kognitif diterapkan selama pengembangan

5) Belajar dapat berpusat pada pembelajar dengan tingkat interaktivitas tinggi.

\section{Apa Itu Computer Based Test?}

Tes Berbasis Komputer (Computer Based Test, CBT) merupakan tes/evaluasi yang diselenggarakan dengan menggunakan komputer. Karakteristik dari tes ini sama dengan tes konvensional yaitu menggunakan satu perangakat tes untuk beberapa peserta dengan panjang tes yang sama (fixed test length). Perbedaannya terletak pada teknik penyampaian (delivery) butir soal yang tidak lagi meggunakan kertas (paperless), baik untuk naskah soal maupun lembar jawaban. Sistem skoring atau koreksi langsung dilakukan oleh komputer. Biasanya peserta bisa mengerjakan dan melihat butir soal dari nomor pertama sampai dengan terakhir.

Ada empat bentuk tes berbasis komputer yang dikembangkan, yaitu :

1. Model Terbuka (Open Mode)

Tes dengan model ini, adalah dimana peserta tes dapat diikuti oleh siapapun tanpa harus melalui registrasi terlebih dahulu dan juga tanpa pengawasan siapapun. Contohnya tes yang dapat 
diakses langsung melalui internet (biasanya berupa games/permainan)

2. Model Terkontrol (Controlled Mode)

Hampir sama dengan Model Terbuka, tapi peserta tes hanya diperuntukkan bagi yang sudah terdaftar dengan cara memasukkan user name dan Password

3. Model Supervisi (Supervisi Mode)

Pada model ini terdapat Supervisor yang mengidentifikasi peserta tes untuk diotentikasi dan memvalidasi kondisi pengambilan tes.

4. Model Pengaturan (Managed Mode)

Pada model ini biasanya tes dilakukan secara terpusat. Organisasi yang mengatur proses tes dapat mendefenisikan dan meyakinkan kinerja dan spesifikasi peralatan di pusat tes. Diperlukan staff/operator yang terlatih untuk mengontrol jalannya tes/evaluasi yang sedang berlangsung ${ }^{2}$.

\section{Kelebihan dan Kekurangan CBT}

Beberapa kelebihan dalam penerapan CBT (contoh kasus pada penerapan Ujian Nasional 2015) antara lain, pihak sekolah bisa menentukan lebih tepat waktu ujian dan para siswa pun bisa menentukan kesiapannya untuk menjalani ujian. Selain itu UN berbasis komputer akan lebih efektif dan efisien karena soal ujian tidak akan habis dan masih dapat digunakan lagi serta mengurangi produksi kertas/ramah lingkungan, selain itu dengan CBT ini dapat meminimalisisr kemungkinan terjadi kebocoran soal.

Kelebihan lainnya mengurangi waktu untuk pekerjaan penilaian tes dan membuat laporan tertulis, menghilangkan pekerjaan logistik seperti mendistribusikan, menyimpan hasil tes dan sebagainya, tapi yang lebih penting yaitu peserta tes dapat langsung mengetahui hasi tes yang telah dilaluinya pada saat itu juga.

Kekurangan penerapan sistem CBT ini adalah tidak ditunjang dengan persedian komputer yang cukup memadai bagi dari segi maintenance maupun segi kuantitas bagi peserta UN di setiap sekolah sehingga mengakibatkan munculnya rasa jenuh bagi para peserta yang menunggu giliran untuk ujian/ test.

Tantangan lain dalam penerapan sistem ini yaitu kemampuan peserta dalam menguasai ketrampilan dalam menggunakan

\footnotetext{
${ }^{2}$ Bartram, Dave SHL Group plc, Thames Ditton, Surrey, UK dan Hambleton, Ronald $\mathrm{K}$, University of Massachusetts at Amherst, USA, Computer-Based Testing and the Internet, 2001
} 
35 | al-Khwarizmi, Volume III, Edisi 2, Oktober 2015, Hal. 31 - 38

komputer tidaklah sama, sehingga bagi mereka yang belum mahir dalam menggunakan alat ini akan tertinggal/lambat dalam penyelesaian testnya nya.selain itu adanya ketergantungan dengan peralatan seperti komputer, membutuhkan lab komputer yang memadai (secara hardware dan software serta jumlah), jika sistem Computer-Based Test bermasalah pelaksanaan tes berbasis komputer akan tertunda.

\section{E. Berbagai Contoh Aplikasi Computer Based Test}

Penelitian awal pada CBT hampir secara eksklusif berfokus pada isu-isu teoritis seperti meningkatkan efisiensi pengukuran dengan mencapai tingkat yang memadai uji skor reliabilitas yang digunakan dengan menggunakan beberapa item yang dibutuhkan dengan tujuan semua peserta ujian memiliki waktu yang cukup untuk menyelesaikan tes/evaluasi yang sedang berlangsung. Dalam beberapa tahun terakhir, penelitian tentang CBT telah difokuskan pada pengembangan model-model yang mempunyai tingkat efisiensi pengukuran sekaligus dapat meminimalkan biaya dan menjaga validitas hasilnya, serta rekayasa kriteria desain dan implementasi untuk memastikan bahwa kelayakan, skalabilitas, dan efisiensi yang dievaluasi sudah tepat.

Berikut beberapa contoh pengembangan CBT yang telah diaplikasikan di beberapa tempat :

1. Pengembangan computer based test pada tes potensi akademik menggunakan skala pengukuran model item response theory (IRT)

Tes potensi akademik merupakan salah satu dari sekian jenis tes yang digunakan untuk mengukur dan memberi penilaian beberapa hal terkait dengan kemampuan dan potensi akademik sesorang dan sejauh ini penggunaannya sudah semakin luas. Misalnya sebagai salah satu pertimbangan dalam menentukan kapasitas dan kapabelitas seseorang yang biasanya disyaratkan dalam kategori tertentu seperti penerimaan siswa atau mahasiswa baru, penerimaan karyawan, seleksi pegawai negeri hingga pengukur kecendrungan pola pikir dan kemampuan intelektual anggota dewan. Bahkan akhir-akhir ini, tes potensi akademik menjadi bagian dari syarat kenaikan jabatan atau posisi-posisi tertentu pada perusahaan dan mulai merambah kearea tes kelayakan (proper test) untuk tugas-tugas tertentu. Pemanfaatan teknologi informasi yang digunakan pada tes potensi akademik berupa tes berbasis komputer (Computer-based Test/ CBT) diharapkan mampu menjawab kebutuhan atas penggunaan tes 
potensi akademik sehingga pengguna dapat melakukan latihan atau menjadikan tes potensi akademik berbasis komputer sebagai media belajar dan bahkan digunakan untuk melakukan pengujian kemampuan bagi tujuan tertentu oleh lembaga, organisasi yang membutuhkan.

Tes potensi akademik berbasis komputer ini menggunakan aplikasi berbasis web dengan konsep Learning Content Management System (LCMS/ CMS) yaitu MOODLE sehingga baik pengelola maupun pengguna dapat dengan mudah menggunkan aplikasi open source ini. Berdasarkan hasil pengujian dan evaluasi dari penggunaan tes potensi akademik berbasis komputer ini menunjukkan bahwa perangkat lunak berbasis web ini dapat digunakan dengan mudah oleh pengguna dan pengelola.

Selanjutnya penerapan tes potensi akademik berbasis komputer ini memiliki fungsi fleksibel berupa pemanfaatan sebagai media latihan maupun mengukur kemampuan pengguna dalam menjawab pertanyaan pada tes potensi akademik.

2. Desain dan pembuatan model testing center untuk latihan ujian CCNA berbasis web

Cisco Systems, Inc. merupakan salah satu perusahaan yang bergerak dibidang penyediaan alat-alat konfigurasi jaringan dan tenaga kerja networking. Dalam rangka mempersiapkan tenaga kerja networking yang handal, Cisco menyediakan berbagai program sertifikasi, misalnya Cisco Certified Network Associate (CCNA), yang merupakan sertifikasi mengenai teknologi jaringan tingkat dasar mengenai penggunaan Cisco router dan switch pada jaringan LAN/WAN. Untuk mendapatkan sertifikasi CCNA tersebut seseorang harus mengikuti ujian sertifikasi. Melalui sistem yang dibuat dengan memanfaatkan teknologi internet ini administrator dapat memilih kategori soal yang akan dibuat, dengan tujuan memudahkan proses monitoring bagi kemajuan peserta kelas pelatihan CCNA (student). Selain fasilitas bagi student melalui freetest, terdapat juga fasilitas bagi non student melalui paidtest, namun untuk fasilitas paidtest ini administrator tidak melakukan monitoring terhadap non student (bukan peserta kelas pelatihan CCNA). Fasilitas lain yang ada misalnya pengaturan aktivasi tes dan konfigurasi tes untuk IP address tertentu dan fasilitas history nilai bagi student dan non student. Sistem ini dikembangkan dengan teknologi PHP dan Java Script serta penggunaan MySQL sebagai database untuk menyimpan semua data yang digunakan dalam sistem. Pengujian terhadap sistem ini menunjukkan bahwa sistem dapat membantu user yang 
37 | al-Khwarizmi, Volume III, Edisi 2, Oktober 2015, Hal. 31 - 38

merupakan student atau non student untuk mendapatkan pelatihan mengenai jaringan komputer. Selain itu user juga mendapat gambaran mengenai bentuk ujian sertifikasi CCNA yang sebenarnya.

3. Multiple Choice Computer-Based Test with Feedback, using Random Number Generator

Pelajar perlu mengerti dan pendidik perlu mengetahui apakah mereka telah mengajarkan pengetahuan mereka dengan baik, keduanya memerlukan umpan balik. Computer Based Test (CBT) membantu untuk mempercepat pemenuhan kebutuhan umpanbalik ini. Beberapa sertifikat profesional juga telah menggunakan CBT, dengan pertanyaan pilihan ganda. Tetapi cara CBT seperti ini, biasanya dipraktekkan dalam laboratorium komputer yang tempat duduknya sangat berdekatan, memberi peluang atau bahkan mengundang orang untuk menyontek.

Salah satu cara untuk mengatasi masalah ini adalah penggunaan randomisasi untuk urutan soal yang muncul dan randomisasi untuk letak pilihan jawaban ganda. Di dalam penelitian ini, Linear Congruential Generator (LCG), suatu fitur randomisasi yang terdapat di dalam Visual Basic (MS VB), digunakan untuk membuat aplikasi CBT yang dibutuhkan.

Dua jenis aplikasi VB yang dibuat, berbasiskan data MS Access atau MS SQL, telah berhasil diuji coba di Laboratorium Komputer UPH oleh lebih dari 200 orang mahasiswa, dalam kelompok kelompok secara paralel (oleh 50 mahasiswa atau kurang untuk subyek seperti: Interaksi Manusia Komputer, Komunikasi Data dan Ujian saring Asisten Lab. Komputer). Tiga tipe hak akses disediakan: administrator, dosen dan mahasiswa.

Seusai CBT, pengguna langsung dapat melihat nilainya, di samping ini, dosen pengampu mata kuliah dapat melihat informasi yang berguna, seperti: pertanyaan mana saja dijawab salah oleh semua pengguna dan sebaliknya, nilai rata-rata kelas, waktu untuk menyelesaikan CBT, data login-logout, nama komputer, serta IPnya. Fitur umpan balik lain pada versi akses dosen adalah, kemampuan CBT untuk memberikan pesan kepada setiap mahasiswa, saat CBT sedang berlangsung. Selain CBT meningkatkan persentase pemakaian jaringan komputer, juga telah berhasil dibuktikan bahwa cara yang dipakai untuk menghasilkan urutan soal dan letak pilihan jawaban secara acak tidak mengganggu pemakai CBT. 


\section{F. Penutup}

Penggunaan Teknologi Pembelajaran mutlak diperlukan dalam mengikuti perkembangan laju Teknologi Informasi dan Komunikasi (ICT) baik dari segi pengembangan media atau sistem pembelajarannya maupun penerapan evaluasi yang dilakukan, sehingga unsur-unsur yang terlibat dalam suatu pembelajaran dapat mendapatkan hasil yang sesuai dengan tujuan yang diinginkan. Evaluasi pembelajaran sebagai bagian dari proses pembelajaran dapat dilakukan dengan sarana Computer-Based Test (tes berbasis komputer). Kesiapan sistem computer-based test dengan dukungan software maupun hardware serta ketrampilan komputer peserta tes menjadi syarat utama dalam pelaksanaan tes berbasis komputer.

\section{DAFTAR PUSTAKA}

Akhmad Sudrajat, Teknologi Pembelajaran,

https://akhmadsudrajat.wordpress.com/2008/04/20/teknologipembelajaran/ [20 April 2008]

Arief S. Sadiman, dkk. 2012. Media Pendidikan, PT. Raja Grafindo Persada. Jakarta

Asnawir, dkk. 2002.Media Pembelajaran, Ciputat Pers. Jakarta

Azhar Arsyad. 2007. Media Pembelajaran, Penerbit Rajawali Pers. Jakarta

Bartram, Dave SHL Group plc, Thames Ditton, Surrey, UK dan Hambleton, Ronald K, University of Massachusetts at Amherst, USA, Computer-Based Testing and the Internet, 2001.

Daniel, Jos (1986). Belajar dan Pembelajaran, Rineka Cipta.Jakarta

Eko. Computer Based Test (CBT), Sebagai Sarana Evaluasi Pembelajaran

http://echo-tea.blogspot.com.posting [29 Maret 2012]

Nurkanca, Wawan. dll. 1990. Evaluasi Hasil Belajar. Usaha Nasional. Surabaya

Purwanto, Ngalim. 1992. Prinsip-prinsip dan Evluasi Pengajaran. Remaja Rosdakarya. Bandung.

Sunarto sunaryo. Pembelajaran Berbasis Komputer. http://staff.uny.ac.id/ [22 Desember 2011]

Wahyudi Setiawan, Computer based Test.

http://wahyudisetiawan.wordpress.com.posting [18 Nopember 2009] 